dr Małgorzata Woźnicka ${ }^{1}$

mgr Elżbieta Przytuła ${ }^{1}$

mgr Dorota Palak-Mazur ${ }^{1}$

\title{
FUNKCJONOWANIE SYSTEMU OCHRONY WÓD PODZIEMNYCH W POLSCE W ŚWIETLE PRZEPISÓW USTAWY PRAWO WODNE
}

https://doi.org/10.18778/8220-655-5.10

\begin{abstract}
Streszczenie: Ramowa Dyrektywa Wodna wprowadziła wysoki priorytet dla ochrony zasobów wodnych, co w polskim prawodawstwie zostało zaimplementowane najpierw ustawą z dnia 18 lipca 2001 r. - Prawo wodne, a następnie uzupełnione ustawą z dnia 20 lipca 2017 r. - Prawo wodne. Wody podziemne, stanowiące strategiczne rezerwy zasobów wodnych oraz podstawę zaopatrzenia ludności w wodę do spożycia, zajmują szczególną pozycję w systemie ochrony wód. Celem ochrony wód podziemnych jest osiągnięcie celów środowiskowych, odnoszących się zarówno do stanu ilościowego (ochrona ilościowa) jak i chemicznego (ochrona jakościowa). Określone cele środowiskowe są osiągane poprzez wdrażanie programów działań w planach gospodarowania wodami na obszarach dorzeczy, przy równoczesnej realizacji przepisów odrębnych dotyczących ochrony środowiska. W artykule przedstawiono zasady i instrumenty prawne służące ochronie wód podziemnych, w świetle przepisów ustawy Prawo wodne, a także aktualny stan zasobów wód podziemnych w Polsce na podstawie wyników oceny stanu jednolitych części wód podziemnych.
\end{abstract}

Słowa kluczowe: wody podziemne, ochrona wód podziemnych, ustawa Prawo wodne, stan jednolitych części wód podziemnych.

\section{Wprowadzenie}

Zgodnie z art. 50 ustawy z dnia 20 lipca 2017 r. Prawo wodne - wody, jako integralna część środowiska oraz siedlisko dla organizmów, niezależnie od tego czyją stanowią własność, podlegają ochronie. Stanowi to implementację celu określonego dla Dyrektywy 2000/60/WE ustanawiającej ramy wspólnotowego działania w dziedzinie polityki wodnej (Ramowa Dyrektywa Wodna - RDW). Na poziomie Unii Europejskiej (UE) zagadnienia związane z ochroną stanu chemicznego wód podziemnych zostały ponadto szczegółowo uregulowane przepisami Dyrektywy 2006/118/WE w sprawie ochrony wód podziemnych przed zanieczyszczeniem i pogorszeniem ich stanu (Dyrektywa Wód Podziemnych - DWP) oraz Dyrektywy 2020/2184 w sprawie jakości wody przeznaczonej do spożycia przez ludzi (Dyrektywa Wód Pitnych).

Poza wymienionymi aktami prawnymi UE w odniesieniu do ochrony wód podziemnych, mają także zastosowanie przepisy dyrektyw powiązanych, w tym 91/676/EWG dotyczącej ochrony wód przed zanieczyszczeniami powodowanymi przez azotany pochodzenia rolniczego (Dyrektywa azotanowa), 91/271/EWG dotyczącej oczyszczania ścieków komunalnych, 91/414/EWG dotyczącej wprowadzania do obrotu środków ochrony roślin oraz 86/278/EWG w sprawie ochrony środowiska, w szczególności gleby, w przypadku wykorzystania osadów ściekowych $w$ rolnictwie.

\footnotetext{
${ }^{1}$ Państwowy Instytut Geologiczny, Państwowy Instytut Badawczy, ul. Rakowiecka 4, 00-975 Warszawa, mwoz@ pgi.gov.pl, ORCID 0000-0002-7840-6049, ORCID 0000-0002-2973-4273, ORCID 0000-0002-9427-6790
} 
Rozbudowana i podlegająca okresowej rewizji legislacja unijna w odniesieniu do zagadnień związanych z ochroną zasobów wodnych na obszarze wspólnoty (Chmielewska i Jezierski 2004, Witczak 2006, Witczak i in. 2012, Woźnicka i Kuczyńska 2019) sprawia, że przepisy krajowe $\mathrm{w}$ tym zakresie podlegają częstym zmianom. Jednocześnie, z uwagi na wielowymiarowy charakter ochrony wód podziemnych, wdrażane mechanizmy i instrumenty prawne są zróżnicowane. Dominują działania zapobiegawcze, co jest zgodne z podstawowymi zasadami polityki ekologicznej UE, takimi jak zasada prewencji i ostrożności. W przypadku stwierdzonego zanieczyszczenia obowiązuje z kolei zasada odpowiedzialności za szkody (zanieczyszczający płaci).

Zgodnie z art. 51 ustawy Prawo wodne głównym celem ochrony wód jest osiągnięcie celów środowiskowych, które w odniesieniu do wód podziemnych w art. 59 zostały zdefiniowane jako:

1) zapobieganie lub ograniczanie wprowadzania do nich zanieczyszczeń;

2) zapobieganie pogorszeniu oraz poprawa ich stanu;

3) ich ochrona i podejmowanie działań naprawczych, a także zapewnianie równowagi między poborem a zasilaniem tych wód, tak aby osiągnąć ich dobry stan.

Działania służące osiągnięciu ustalonych dla jednolitych części wód podziemnych (JCWPd) celów środowiskowych, polegają w szczególności na stopniowym redukowaniu zanieczyszczenia wód podziemnych przez odwracanie znaczących i utrzymujących się tendencji wzrostowych zanieczyszczenia powstałego w wyniku działalności człowieka, przy czym cele środowiskowe realizuje się poprzez podejmowanie działań zawartych w planach gospodarowania wodami na obszarze dorzeczy (art. 60 ustawy Prawo wodne). Podstawowym celem środowiskowym dla JCWPd jest utrzymanie lub osiągnięcie dobrego stanu, definiowanego jako stan osiągnięty przez jednolitą część wód podziemnych, jeżeli zarówno jej stan ilościowy, jak i chemiczny jest oceniony jako „dobry”. Ogólny stan JCWPd określany jest zatem na podstawie oceny stanu ilościowego oraz oceny stanu chemicznego, przy czym o wyniku końcowym oceny stanu JCWPd decyduje gorszy wynik powyższych składowych oceny (Palak-Mazur i in. 2020a).

Ramowa Dyrektywa Wodna dopuszcza wprowadzenie odstępstw od osiągnięcia ustalonych dla poszczególnych JCWPd celów środowiskowych (derogacji), poprzez zastosowanie procedury określonej $\mathrm{w}$ art. 4.4-4.7 RDW (przedłużenie terminu osiągnięcia celów środowiskowych bądź ustanowienie mniej rygorystycznego celu). Procedury te jednak mogą mieć zastosowanie wyłącznie przy spełnieniu szeregu warunków oraz uzasadnieniu wskazującym, iż podjęte zostały wszystkie możliwe do wykonania działania, aby ograniczyć niekorzystny wpływ na stan wód. W aktualnym cyklu planistycznym procedurą derogacji objętych jest 21 JCWPd, w tym: $9 \mathrm{z}$ tytułu art. 4.4 RDW (odstępstwo czasowe), $10 \mathrm{z}$ tytułu art. 4.5 (ustalenie mniej rygorystycznego celu) oraz 2 JCWPd z uwagi na zastosowanie obydwu przesłanek. 
Małgorzata Woźnicka, Elżbieta Przytuła, Dorota Palak-Mazur

\section{Ochrona ilościowa wód podziemnych (utrzymanie/osiągnięcie dobrego stanu ilościowego JCWPd)}

Ochrona ilościowa wód podziemnych, rozumiana jako utrzymanie lub osiągnięcie dobrego stanu ilościowego jednolitych części wód podziemnych, powinna być wdrożona w planach gospodarowania wodami na obszarze dorzeczy. Podstawę do prowadzenia efektywnej ochrony ilościowej stanowi wynik bilansu wodnego, uwzględniającego wielkość zasobów oraz poboru (stopień wykorzystania zasobów wód podziemnych/rezerwy zasobów). Należy przy tym zwrócić uwagę na funkcjonujące w polskim prawodawstwie dwie definicje odnoszące się do zasobów wód podziemnych.

Podstawę bilansowania wód podziemnych stanowią zasoby dyspozycyjne wód podziemnych (ZD), ustalane w jednostkach bilansowych, rozumianych jako wyznaczone do przeprowadzania bilansu wodnogospodarczego zlewnie rzek, będących w związku hydraulicznym z wodami podziemnymi, obejmujące strefy zasilania ujęć wód podziemnych. Obecnie na obszarze Polski wydzielonych jest 109 obszarów bilansowych oraz 676 mniejszych jednostek bilansowych - rejonów wodnogospodarczych. Zasoby dyspozycyjne wód podziemnych są ustalane zgodnie z ustawą Prawo geologiczne i górnicze oraz rozporządzeniem Ministra Środowiska z dnia 18 listopada 2016 r. $w$ sprawie dokumentacji hydrogeologicznej i dokumentacji geologiczno-inżynierskiej oraz wytycznymi Poradnika metodycznego (Herbich i in. 2013) w trybie sporząadzenia dokumentacji hydrogeologicznej, zatwierdzanej przez ministra właściwego do spraw środowiska. Są one określane w ilościach średnich wieloletnich zgodnie z przebiegiem ich odnawialności, właściwym dla warunków hydrogeologicznych panujących w jednostkach bilansowych, z zastosowaniem metod modelowania matematycznego przepływu wód podziemnych, prognozowanego $\mathrm{w}$ warunkach dopuszczalnego stopnia zagospodarowania zasobów z zachowaniem celów środowiskowych w obszarach chronionych. Model matematyczny powstaje na podstawie szczegółowej analizy wyników rozpoznania geologicznego, hydrogeologicznego i hydrologicznego, uzupełnionego zaprojektowanymi badaniami i pomiarami terenowymi, stanowiąc kluczowy element dokumentacji hydrogeologicznej ustalającej zasoby dyspozycyjne wód podziemnych (Przytuła 2015).

Według stanu rozpoznania na dzień 31 grudnia 2020 roku, zasoby dyspozycyjne (ZD) zwykłych wód podziemnych wynoszą dla obszaru całego kraju około $12,4 \mathrm{~km}^{3} /$ rok (około $34 \mathrm{mln} \mathrm{m}^{3} /$ dobę). W tej wartości około 50 tys. $\mathrm{m}^{3} /$ dobę stanowią zasoby perspektywiczne (ZP) oszacowane dla ok. 1\% powierzchni Polski. Dla dwóch największych dorzeczy, wielkości zasobów wód podziemnych przedstawiają się następująco:

- dla obszaru dorzecza Wisły zasoby wód podziemnych wynoszą ok. $6,75 \mathrm{~km}^{3} /$ rok (ok. $18,49 \mathrm{mln} \mathrm{m}^{3} /$ dobę), co - uwzględniając powierzchnię tego obszaru (ok. 183,2 tys. $\mathrm{km}^{2}$ ) - daje średnią wartość modułu zasobów dyspozycyjnych zwykłych wód podziemnych równą 101,0 $\mathrm{m}^{3} /$ dobę $\mathrm{km}^{2}$;

- dla obszaru dorzecza Odry zasoby wód podziemnych wynoszą ok. $5,2 \mathrm{~km}^{3} /$ rok (ok. $14,27 \mathrm{mln} \mathrm{m}^{3} /$ dobę), co - uwzględniając powierzchnię dorzecza (ok. 118,0 tys. $\mathrm{km}^{2}$ ) - daje średnią w tym dorzeczu wartość modułu zasobów dyspozycyjnych około $120,9 \mathrm{~m}^{3} /$ dobę $\mathrm{km}^{2}$. 
W odniesieniu do jednolitych części wód podziemnych ustawa Prawo wodne wprowadza pojęcie dostępnych zasobów wód podziemnych (ZDG). Danymi wejściowymi dla określenia ich wielkości w JCWPd, zależnie od dostępności danych są: zasoby dyspozycyjne wód podziemnych (ZD) ustalone w jednostkach bilansowych w ramach dokumentacji hydrogeologicznej lub zasoby perspektywiczne (ZP) określone w sposób oszacowany na podstawie metod hydrologicznych. W metodyce stosowanej na potrzeby realizacji zadań państwowej służby hydrogeologicznej zasoby dostępne wód podziemnych są przeliczane, z zastosowaniem wartości modułów zasobów dyspozycyjnych (i/lub perspektywicznych) charakteryzujących dany rejon wodnogospodarczy, na sumaryczną wartość zasobów w obrębie JCWPd, przy uwzględnieniu udziału w danej JCWPd powierzchni poszczególnych rejonów wodnogospodarczych.

Rozkład wielkości zasobów dyspozycyjnych w jednostkach bilansowych oraz zasobów dostępnych w JCWPd przedstawiają odpowiednio ryc. 1 i ryc. 2.

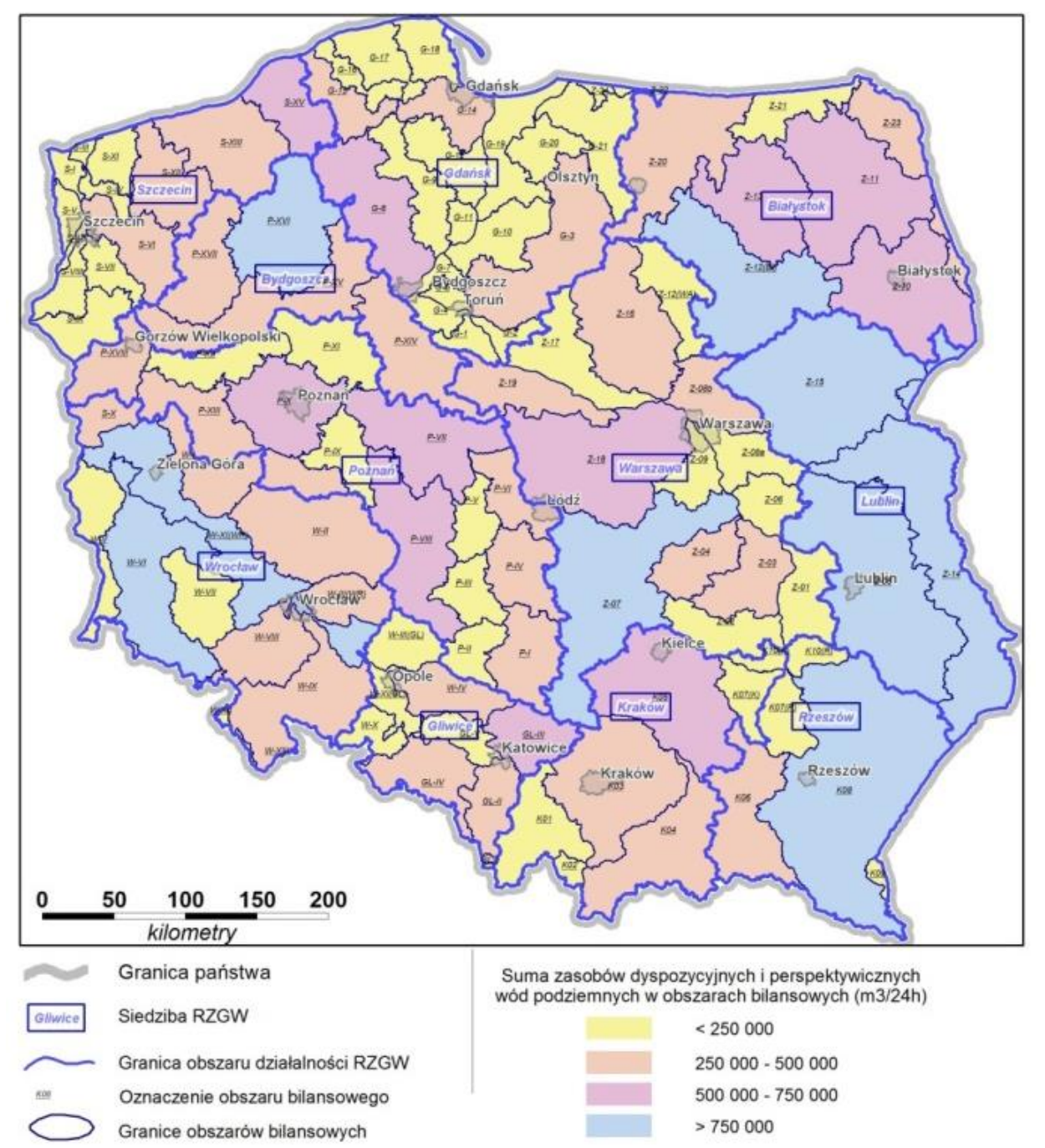

Ryc. 1. Mapa zasobów dyspozycyjnych wód podziemnych w obszarach bilansowych (stan na 31.12.2020 r.)

Źródło: Państwowa Służba Hydrogeologiczna 


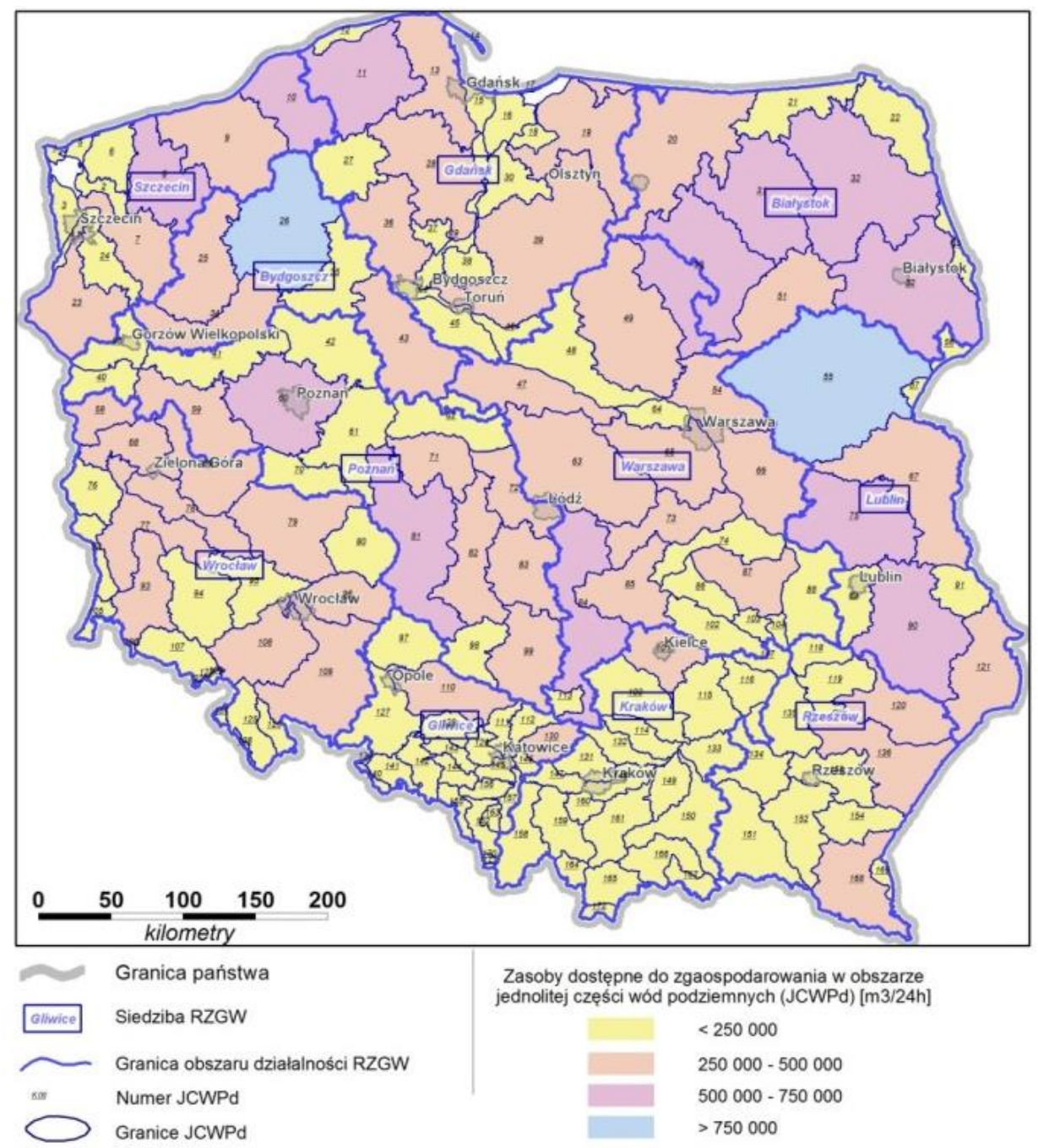

Ryc. 2. Mapa dostępnych zasobów wód podziemnych w JCWPd (stan na 31.12.2020 r.) Źródło: Państwowa Służba Hydrogeologiczna

Zasoby dostępne w JCWPd, stanowiące podstawę do oceny stanu JCWPd, są pochodną zasobów dyspozycyjnych ustalanych dla jednostek bilansowych, co jest zgodne z definicją jednolitych części wód podziemnych wskazaną w art. 24 ustawy Prawo wodne, ale może prowadzić do rozbieżności w interpretacji wyników, jeżeli na potrzeby innych zadań zostanie przyjęta odmienna metodyka przeliczenia wielkości zasobów dyspozycyjnych na zasoby dostępne (Sadurski i Śmietański 2015). Należy także podkreślić, iż w przeciwieństwie do zasobów dyspozycyjnych, zasoby dostępne w JCWPd nie podlegają zatwierdzaniu w trybie procedur administracyjnych, więc wydawanie decyzji na ich podstawie (np. naliczanie wysokości opłaty stałej za pobór wód, której stawka jest uzależniona od stopnia wykorzystania zasobów dostępnych) może być podważane. 
$\mathrm{Z}$ tego względu zasadne wydaje się przeprowadzenie integracji jednostek bilansowych oraz jednolitych części wód podziemnych, co przyczyni się z jednej strony do istotnego zwiększenia dokładności oceny stanu ilościowego wód podziemnych, zaś z drugiej umożliwi prowadzenie zrównoważonego gospodarowania wodami i efektywną ochronę ilościową wód podziemnych. W efekcie JCWPd będą mogły pełnić swoją funkcję jako jednostki, w których zarządzanie wodami będzie oparte na bilansie wodnym w mniejszych jednostkach bilansowych (rejonach wodnogospodarczych). Umożliwi to również dokonywanie podziału poszczególnych JCWPd na subczęści zgodne z wydzielonymi rejonami wodnogospodarczymi, co stworzy warunki oceny stanu ilościowego wód podziemnych w rejonie oddziaływania intensywnego poboru wód podziemnych na stan ich bilansu i ekosystemów od nich zależnych.

Drugi element bilansu wodnego stanowi wielkość poboru wód podziemnych. Podstawowym źródłem danych w tym zakresie jest informacja na temat ilości wód pobieranych z ujęć działających na potrzeby zaopatrzenia ludności wodę do spożycia oraz rolnictwa i przemysłu. Informacja ta do 2017 roku pozyskiwana była $\mathrm{z}$ baz opłatowych prowadzonych przez urzędy marszałkowskie (Felter i in. 2012), zaś od roku 2018, zgodnie z przepisami ustawy z dnia 20 lipca 2017 r. - Prawo wodne, źródłem danych referencyjnych jest baza Eden, do której użytkownicy zgłaszają co kwartał wielkość poboru wód. Baza ta prowadzona jest przez poszczególne zarządy zlewni, będące jednostkami regionalnymi Państwowego Gospodarstw Wodnego Wody Polskie. Istotnym elementem jest również pobór prowadzony w ramach odwodnienia kopalń: terenów zarówno czynnych jak i nieczynnych zakładów górniczych. Odwadnianie części nieczynnych już zakładów górniczych jest konieczne, aby uchronić przed zalaniem położone niżej wyrobiska sąsiednich, czynnych kopalń. Problem ten dotyczy przede wszystkim Górnośląskiego Zagłębia Węglowego (GZW).

Według informacji zgromadzonych na koniec 2020 r. pobór rejestrowany wód podziemnych w Polsce wynosił około $2,7 \mathrm{~km} /$ rok. Na tę ilość składają się:

- pobór rejestrowany zwykłych wód podziemnych z ponad 18000 ujęć wód działających na potrzeby zaopatrzenia ludności i przemysłu w wodę, wynoszący $1,77 \mathrm{~km} 3 / \mathrm{rok}$ (wg danych za 2018 r.),

- pobór wód w ramach odwodnień górniczych (czynnych i nieczynnych) dla ponad 120 . zakładów, wynoszący łącznie $0,96 \mathrm{~km} 3 / \mathrm{rok}$ (wg danych za 2019 r.). Według informacji zgłaszanych przez zakłady górnicze z podanej wartości rocznie około $10 \%$ wód podziemnych podlega wykorzystaniu na potrzeby kopalń i zaopatrzenia ludności, zaś około $90 \%$ podlega zrzutowi do wód powierzchniowych.

Podana wartość poboru nie obejmuje tzw. poboru nierejestrowanego wód podziemnych - tzn. niezgłoszonego przez użytkowników, wynikającego z luk ewidencyjnych oraz poboru w ramach zwykłego korzystania z wód. Szacuje się, że pobór nierejestrowany może stanowić ok. 30\% poboru rejestrowanego, a regionalnie osiągać nawet dużo wyższe wartości (Frankowski i in. 2009). Rozkład wielkości poboru rejestrowanego wód podziemnych w jednostkach bilansowych oraz w JCWPd przedstawiają odpowiednio ryc. 3 i ryc. 4. 
Małgorzata Woźnicka, Elżbieta Przytuła, Dorota Palak-Mazur

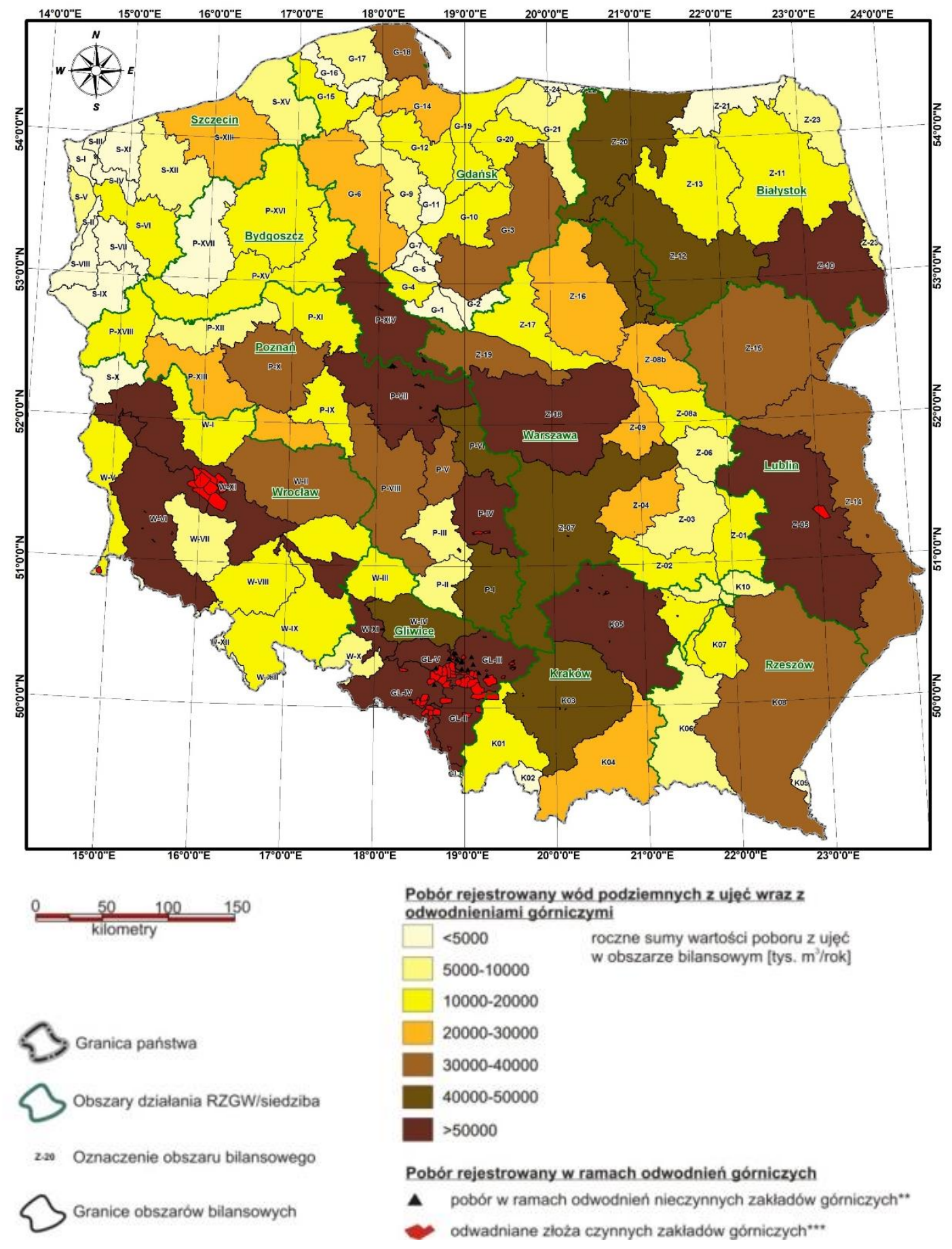

Ryc. 3. Mapa poglądowa rocznej sumy poboru rejestrowanego wód podziemnych w obszarach bilansowych Źródło: Państwowa Służba Hydrogeologiczna 
Funkcjonowanie systemu ochrony wód podziemnych w Polsce w świetle przepisów ustawy Prawo wodne

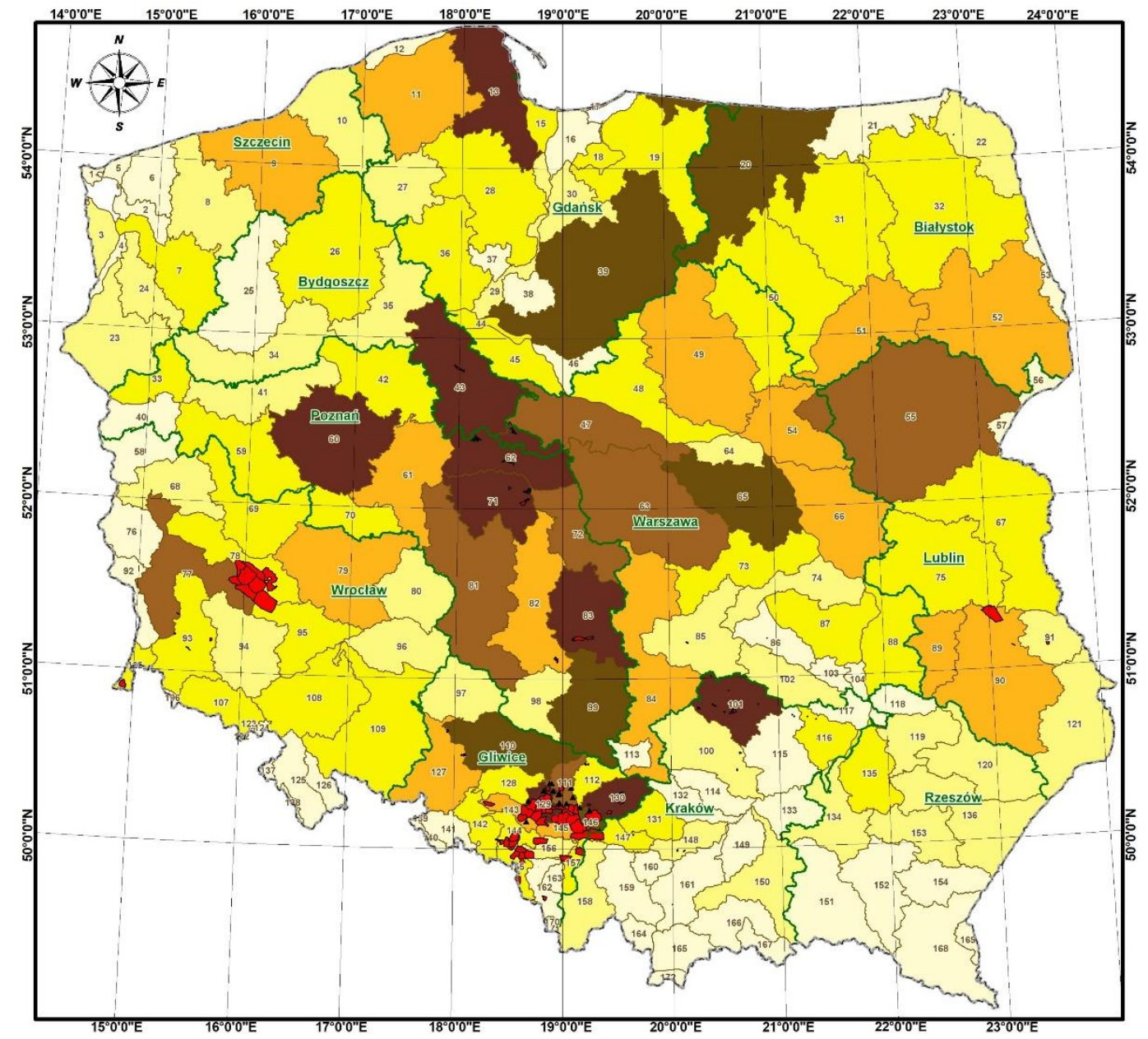

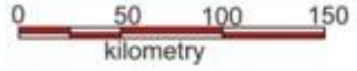

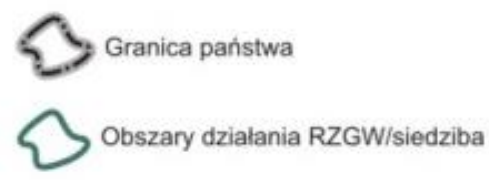

" Oznaczenie JCWPd

Granice JCWPd

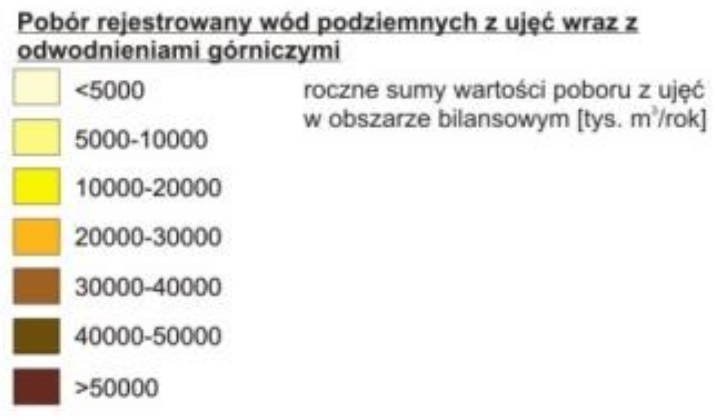

Pobór rejestrowany wód podziemnych z ujęć wraz z odwodnieniami górniczymi

$\square=000$
$\begin{aligned} & \square 000 \\ & 5000-10000\end{aligned}$
$10000-20000$
$20000-30000$
$30000-40000$
$40000-50000$
$>50000$

Pobór rejestrowany w ramach odwodnien górniczych

A pobór w ramach odwodnień nieczynnych zakiadów gómiczych** odwadniane zloża czynnych zakladów gómiczych ***

Ryc. 4. Mapa poglądowa rocznej sumy poboru rejestrowanego wód podziemnych w JCWPd Źródło: Państwowa Służba Hydrogeologiczna 
Stopień wykorzystania zasobów dyspozycyjnych zwykłych wód podziemnych został określony na podstawie stanu rozpoznania ilości zasobów na koniec 2020 r. i wielkości poboru dla 2018 r. (Biuletyn PSH 2020 - sprawozdanie z realizacji zadań Państwowej Służby Hydrogeologicznej w 2020 r.). Dla obszaru całego kraju stopień wykorzystania zasobów zwykłych wód podziemnych wynosi około $22 \%$. W dorzeczu Wisły wartość tego wskaźnika wynosi niespełna $20 \%$, natomiast w dorzeczu Odry około $24 \%$. Wartości te oznaczają, że stan rezerw zasobów wód podziemnych dostępnych do zagospodarowania w skali roku w powyższych dorzeczach wynosi odpowiednio: około $80 \%$ w dorzeczu Wisły oraz $76 \%$ w dorzeczu Odry (tab. 1).

Tab. 1. Stopień wykorzystania zasobów wód podziemnych w podziale na dorzecza i regiony wodne

\begin{tabular}{|c|c|c|c|c|}
\hline \multirow[t]{2}{*}{ Dorzecze } & \multirow[t]{2}{*}{ Region wodny } & $\begin{array}{c}\text { Zasoby wód } \\
\text { podziemnych } \\
\text { lącznie } \\
(\mathrm{ZG}=\mathrm{ZD}+\mathrm{ZP})\end{array}$ & $\begin{array}{l}\text { Suma poboru } \\
\text { rejestrowanego } \\
\text { z ujęć i odwodnień } \\
\text { górniczych (POB) }\end{array}$ & $\begin{array}{c}\text { Stopień wykorzystania } \\
\text { zasobów wód } \\
\text { podziemnych (POB/ZG) }\end{array}$ \\
\hline & & mln m³/rok & mln m³/rok & $\%$ \\
\hline \multirow{2}{*}{ Banówki } & Razem dorzecze Banówki & 5,457 & 0,102 & 1,9 \\
\hline & Banówki & 5,457 & 0,102 & 1,9 \\
\hline \multirow{2}{*}{ Dniestru } & Razem dorzecze Dniestru & 17,851 & $\mathbf{0 , 0 3 1}$ & 0,2 \\
\hline & Dniestru & 17,851 & 0,031 & 0,2 \\
\hline \multirow{4}{*}{ Dunaju } & Razem dorzecze Dunaju & 8,410 & 0,152 & 1,8 \\
\hline & Czadeczki & 0,239 & 0,066 & 27,6 \\
\hline & Czarnej Orawy & 8,140 & 0,086 & 1,1 \\
\hline & Morawy & 0,031 & 0,000 & 0,0 \\
\hline \multirow{5}{*}{ Laby } & Razem dorzecze Laby & 8,111 & 0,166 & 2,0 \\
\hline & Izery & 2,190 & 0,000 & 0,0 \\
\hline & Łaby i Ostrożnicy (Upa) & 0,860 & 0,000 & 0,0 \\
\hline & Metuje & 4,399 & 0,166 & 3,8 \\
\hline & Orlicy & 0,662 & 0,000 & 0,0 \\
\hline \multirow{2}{*}{ Niemna } & Razem dorzecze Niemna & $\mathbf{1 0 5 , 8 6 4}$ & 7,663 & 7,2 \\
\hline & Niemna & 105,864 & 7,663 & 7,2 \\
\hline \multirow{6}{*}{ Odry } & Razem dorzecze Odry & 5208,881 & 1260,659 & 24,2 \\
\hline & Dolnej Odry i Przymorza Zachodniego & 890,075 & 77,504 & 8,7 \\
\hline & Górnej Odry & 463,950 & 124,933 & 26,9 \\
\hline & Noteci & 723,104 & 90,152 & 12,5 \\
\hline & Środkowej Odry & 1534,861 & 283,262 & 18,4 \\
\hline & Warty & 1596,891 & 685,808 & 42,9 \\
\hline \multirow{2}{*}{ Pregoły } & Razem dorzecze Pregoły & 216,918 & $\mathbf{3 1 , 3 2 7}$ & 14,4 \\
\hline & Łyny i Węgorapy & 216,918 & 31,327 & 14,4 \\
\hline \multirow{2}{*}{ Świeżej } & Razem dorzecze Świeżej & 4,649 & 0,204 & 4,4 \\
\hline & Świeżej & 4,649 & 0,204 & 4,4 \\
\hline \multirow{8}{*}{ Wisły } & Razem dorzecze Wisły & 6750,306 & 1309,132 & 19,4 \\
\hline & Bugu & 1148,023 & 136,323 & 11,9 \\
\hline & Dolnej Wisły & 1301,547 & 235,524 & 18,1 \\
\hline & Górnej-Wschodniej Wisły & 690,865 & 56,490 & 8,2 \\
\hline & Górnej-Zachodniej Wisły & 711,198 & 144,000 & 20,2 \\
\hline & Małej Wisły & 353,974 & 334,093 & 94,4 \\
\hline & Narwi & 931,326 & 81,948 & 8,8 \\
\hline & Środkowej Wisły & 1613,373 & 322,754 & 20,0 \\
\hline \multicolumn{2}{|c|}{ Suma dla obszaru kraju } & 12326,447 & 2609,436 & 21,2 \\
\hline
\end{tabular}

Źródło: Państwowa Służba Hydrogeologiczna. 
Regionami wodnymi o najintensywniejszej eksploatacji zwykłych wód podziemnych są: region wodny Małej Wisły w dorzeczu Wisły oraz region wodny Warty w dorzeczu Odry. Wysokie wartości rocznego wykorzystania zasobów w tych regionach wynikają głównie z lokalizacji $\mathrm{w}$ ich granicach odwadnianych obszarów górniczych, zwłaszcza węgla kamiennego w GZW na obszarze regionu wodnego Małej Wisły oraz węgla brunatnego w regionie wodnym Warty. Należy tu podkreślić, że wysoka wartość stopnia wykorzystania zasobów wynika z poboru obejmującego sczerpywanie zasobów statycznych wód podziemnych w lejach depresji odwadnianych kopalń oraz występującego tam dodatkowego zasilania wód podziemnych, nie uwzględnianego w ustalaniu zasobów dyspozycyjnych. Należy podkreślić fakt, że około $90 \%$ z ilości wód pobieranych przez systemy odwadniania kopalń jest zrzucane do wód powierzchniowych, a więc wraca do obiegu wody w środowisku. W innych regionach wodnych dorzeczy Wisły i Odry stopień wykorzystania zasobów wynosi średnio kilkanaście procent. Na obszarze pozostałych dorzeczy jego wartości są bardzo niskie - poniżej 1\% lub na poziomie kilku procent (tab. 1).

Efektywna ochrona ilościowa wód podziemnych powinna być prowadzona na podstawie bieżącego i prognozowanego wyniku bilansu wodnogospodarczego, przeprowadzanego w jednostkach bilansowych i polegać na wykorzystywaniu zasobów wodnych zgodnie z przyjętymi priorytetami i hierarchią poszczególnych użytkowników wód. Ustawa Prawo wodne wprowadza szereg instrumentów prawnych służących tak rozumianej ochronie ilościowej wód podziemnych. Należą do nich w szczególności:

1) ustalenie kryteriów dla zwykłego korzystania z wód;

2) mechanizm zgody wodnoprawnej (wydanie pozwolenia wodnoprawnego dla szczególnego korzystania z wód, przyjęcie zgłoszenia wodnoprawnego bądź wydanie oceny wodnoprawnej);

3) ustalenie hierarchii dla użytkowników wód podziemnych;

4) zasada zwrotu kosztu usług wodnych;

5) procedury kontroli gospodarowania wodami;

6) planowanie w gospodarowaniu wodami, w tym:

a) plany gospodarowania wodami na obszarze dorzeczy;

b) plany zarządzania ryzykiem powodziowym;

c) plan przeciwdziałania skutkom suszy.

Ustanowienie limitu ilości poboru wód w ramach zwykłego korzystania z wód, które służy zaspokojeniu potrzeb własnego gospodarstwa domowego lub rolnego stanowi jedną z ważniejszych zasad ochrony ilościowej zasobów wodnych (art. 33 ustawy Prawo wodne).

W założeniu pobór w ilości nieprzekraczającej średniorocznie $5 \mathrm{~m}^{3}$ na dobę jest bezpieczną granicą dla użytkowania wód podziemnych i nie prowadzi do pogorszenia stanu ilościowego. Jednakże, z uwagi na wyłączenie poboru w ramach zwykłego korzystania z wód z obowiązku opomiarowania (art. 36, ust. 3 ustawy Prawo wodne), w połączeniu z wyłączeniem spod przepisów ustawy Prawo geologiczne i górnicze, ujęć wód podziemnych do głębokości do $30 \mathrm{~m}$, zarówno liczba takich ujęć, jak też ilość wody z nich pobierana pozostają poza jakąkolwiek ewidencją. Stwarza to trudności w przeprowadzaniu bilansów wodnogospodarczych, a ponadto $\mathrm{w}$ określonych sytuacjach niekontrolowany, intensywny pobór może mieć realny 
wpływ na stan ilościowy wód podziemnych i rozwój regionalnego obniżenia zwierciadła wód podziemnych (Matusiak i Przybyłek 2017).

W obszarze szczególnego korzystania z wód najważniejszym instrumentem prawnym, mającym bezpośredni wpływ na użytkowanie wód podziemnych, a tym samym ich ochronę ilościową jest pozwolenie wodnoprawne, wydawane w drodze decyzji na czas określony, ale nie dłuższy niż 30 lat, przez organy regionalne Państwowego Gospodarstwa Wodnego Wody Polskie (dyrektor właściwego terytorialnie regionalnego zarządu gospodarki wodnej). W aspekcie ochrony zasobów wód podziemnych pozwolenie wodnoprawne ma zastosowanie nie tylko w odniesieniu do usług wodnych związanych z poborem wód podziemnych, ale także do innej działalności prowadzonej w ramach szczególnego korzystania $\mathrm{z}$ wód oraz długotrwałego obniżenia poziomu zwierciadła wody podziemnej i wykonywania urządzeń wodnych. Pozwolenie wodnoprawne nie może naruszać planu gospodarowania wodami na obszarze dorzeczy, a jednocześnie należy podkreślić, iż ustawa Prawo wodne w art. 415 określa przypadki, w których można cofnąć lub ograniczyć pozwolenie wodnoprawne bez odszkodowania. W odniesieniu do ochrony stanu ilościowego wód podziemnych zastosowanie mają następujące przesłanki:

1) zasoby wód podziemnych uległy zmniejszeniu w sposób naturalny;

2) nastąpiło zagrożenie osiągnięcia celów środowiskowych i jest to uzasadnione danymi z monitoringu wód oraz wynikami dodatkowego przeglądu pozwoleń wodnoprawnych, o którym mowa w art. 325, ust. 1, pkt 2 ustawy Prawo wodne.

Poza wyżej wymienionymi zasadami określonymi w ustawie Prawo wodne, w kontekście ochrony ilościowej wód podziemnych zastosowanie mają także przepisy odrębne dotyczące procedur przeprowadzania ocen oddziaływania na środowisko przedsięwzięć mogących znacząco oddziaływać na środowisko (ustawa z dnia 3 października 2008 r. o udostępnianiu informacji o środowisku i jego ochronie, udziale społeczeństwa w ochronie środowiska oraz o ocenach oddziaływania na środowisko - Dz.U. z 2021 r., poz. 247, 784, 922, 1211).

$\mathrm{Z}$ uwagi na fakt, iż wszystkie wydzielone na obszarze Polski jednolite części wód podziemnych spełniają określone w art. 72 ustawy Prawo wodne kryteria zaliczenia ich do jednolitych części wód przeznaczonych do poboru wody na potrzeby zaopatrzenia ludności w wodę do spożycia przez ludzi, względem obszaru całego kraju mają zastosowanie przepisy ustawy $\mathrm{z}$ dnia 7 czerwca 2001 r. o zbiorowym zaopatrzeniu $w$ wodę i zbiorowym odprowadzaniu ścieków (Dz.U. z 2020 r., poz. 2028).

\section{Ochrona jakościowa (utrzymanie/osiągnięcie dobrego stanu chemicznego JCWPd)}

Ochrona jakościowa, rozumiana jako utrzymanie bądź osiągnięcie dobrego stanu chemicznego jednolitych części wód podziemnych, realizowana jest na podstawie przepisów ustawy Prawo wodne poprzez wprowadzenie szeregu zakazów lub ograniczeń w użytkowaniu terenu bądź stosowaniu określonych substancji. Stanowi to wypełnienie nadrzędnej zasady ochrony wód podziemnych przed zanieczyszczeniem (zasada prewencji). Do tego rodzaju uregulowań należą w szczególności:

1) zakaz wprowadzania ścieków bezpośrednio do wód podziemnych; 
Funkcjonowanie systemu ochrony wód podziemnych w Polsce w świetle przepisów ustawy Prawo wodne

2) zakaz wprowadzania ścieków do ziemi zgodnie z warunkami określonymi w art. 75, pkt 3 ustawy Prawo wodne;

3) zakaz wprowadzania wód opadowych lub roztopowych, ujętych w otwarte lub zamknięte systemy kanalizacji deszczowej, służące do odprowadzania opadów atmosferycznych bezpośrednio do wód podziemnych;

4) ograniczenia w rolniczym wykorzystaniu ścieków, zgodnie z art. 84, ust. 4 ustawy Prawo wodne;

5) wdrożenie programu działań mających na celu zmniejszenie zanieczyszczenia wód azotanami pochodzącymi ze źródeł rolniczych oraz zapobieganie dalszemu zanieczyszczeniu (tzw. program azotanowy);

6) realizacja krajowego programu oczyszczania ścieków komunalnych.

Poza wyżej wymienionymi, ochronie stanu chemicznego zasobów wodnych służą także wskazania i zalecenia, przewidziane do dobrowolnego stosowania. Należy do nich m.in. zbiór zaleceń dobrej praktyki rolniczej, obejmujący wskazówki dotyczące okresów i sposobu nawożenia, sposobu przechowywania nawozów naturalnych i innych.

Inną formę ochrony jakościowej wód podziemnych stanowi ustanawianie stref i obszarów ochronnych. Zgodnie z art. 120 ustawy Prawo wodne zapewnieniu odpowiedniej jakości wód ujmowanych do zaopatrzenia ludności w wodę przeznaczoną do spożycia przez ludzi oraz zaopatrzenia zakładów wymagających wody wysokiej jakości, a także ochronie zasobów wodnych służy ustanawianie:

1) stref ochronnych ujęć wody;

2) obszarów ochronnych zbiorników wód śródlądowych (w odniesieniu do wód podziemnych rozumianych jako główne zbiorniki wód podziemnych).

Główne zbiorniki wód podziemnych (GZWP) to struktury geologiczne lub ich fragmenty, wykazujące w skali regionów hydrogeologicznych najwyższą zasobność. Stanowią one obecnie lub w przyszłości strategiczne rezerwy zasobów wodnych, jako źródło zaopatrzenia w wodę do spożycia przez ludzi. Ze względu na kryteria wydzielania: wysoką jakość wód, zasobność i potencjalną wysoką wydajność ujęć, GZWP stanowią najcenniejsze fragmenty jednostek hydrostrukturalnych oraz systemów wodonośnych i zgodnie z ustawą Prawo wodne podlegają ochronie (Herbich i in. 2011). Ochrona GZWP realizowana jest poprzez ustanawianie dla nich obszarów ochronnych, w zasięgu których mogą obowiązywać zakazy lub ograniczenia w zakresie użytkowania gruntów lub korzystania z wód, w celu ochrony zasobów tych wód, przede wszystkim przed degradacją ich jakości (stanu chemicznego). Obszar ochronny GZWP ustanawiany jest przez właściwego terytorialnie wojewodę, na wniosek Wód Polskich, w drodze aktu prawa miejscowego (art. 141 ustawy Prawo wodne). W Polsce wydzielone są 163 zbiorniki (ryc. 5), obejmujące łącznie powierzchnię $174284 \mathrm{~km}^{2}$ (55,7\% powierzchni kraju) w tym:

- 141 głównych zbiorników wód podziemnych (GZWP udokumentowane);

- 20 lokalnych zbiorników wód podziemnych (LZWP udokumentowane);

- 2 zbiorniki nieudokumentowane. 
Projektowane obszary ochronne dla udokumentowanych GZWP/LZWP obejmują łącznie ok. 20\% powierzchni kraju. Do końca 2020 r. dla żadnego GZWP nie ustanowiono obszaru ochronnego. W ramach realizacji działań zawartych w Planach gospodarowania wodami na obszarze dorzeczy, od 2016 r. realizowane są prace mające na celu ustanowienie obszarów ochronnych dla kilkunastu GZWP. Wykonane zostały analizy kosztów i korzyści ustanowienia obszarów ochronnych, a dla kilku GZWP zostały już złożone wnioski do wojewody. Planowana jest kontynuacja tych działań w kolejnym cyklu planistycznym w latach 2022-2027.

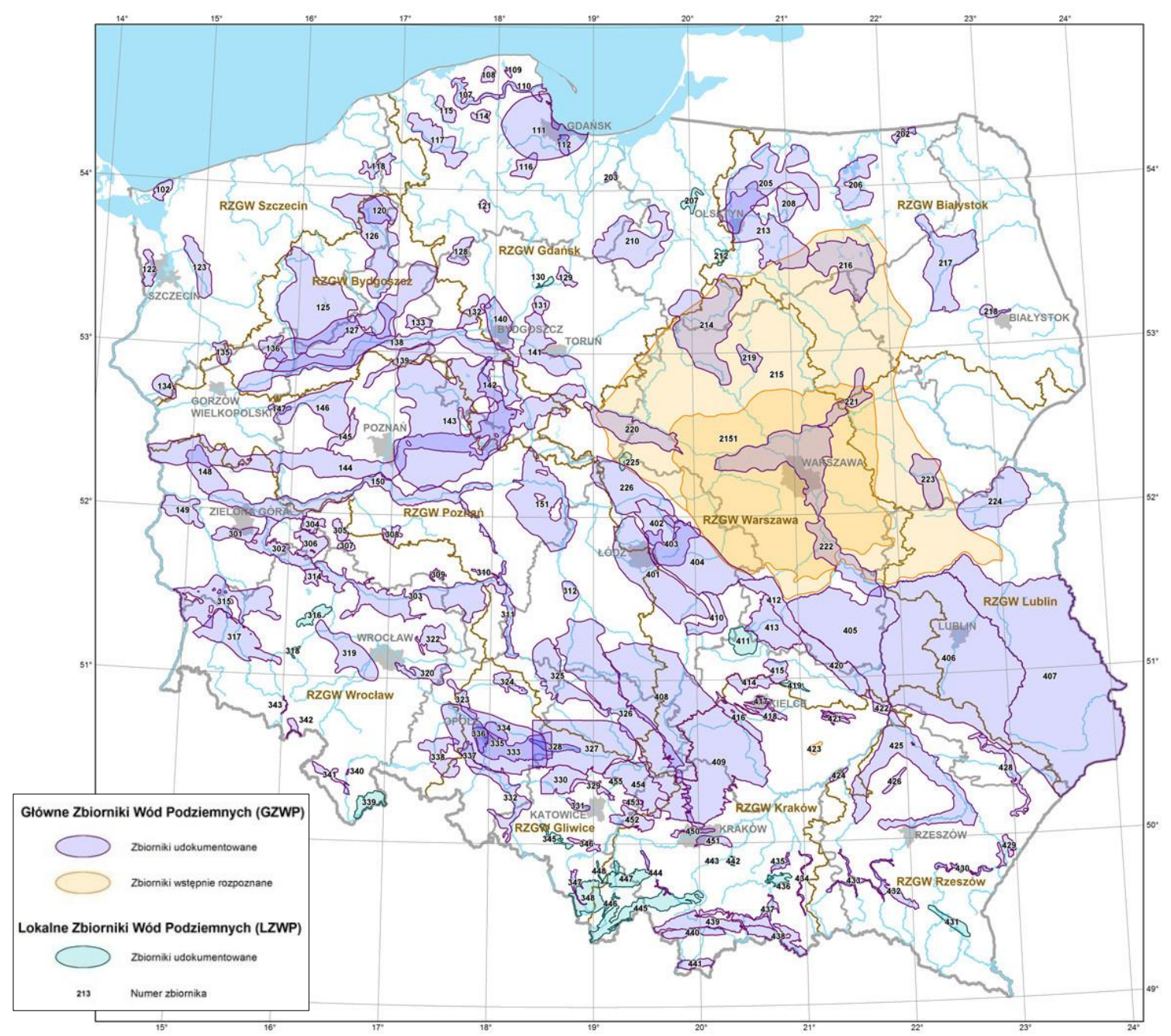

Ryc. 5. Główne i lokalne zbiorniki wód podziemnych wydzielone i udokumentowane na obszarze Polski Źródło: Państwowa Służba Hydrogeologiczna

Strefy ochronne ujęć wód podziemnych stanowią obszary, na których obowiązują nakazy, zakazy i ograniczenia w zakresie użytkowania gruntów oraz korzystania z wód. Strefa ochronna ujęcia wody podziemnej, obejmująca wyłącznie teren ochrony bezpośredniej, ustanawiana jest przez PGW Wody Polskie, zaś obejmująca teren ochrony bezpośredniej i dodatkowo teren ochrony pośredniej - przez wojewodę. 
Ustanowienie strefy ochronnej obejmującej teren ochrony bezpośredniej jest obowiązkowe dla wszystkich ujęć wód, z wyłączeniem ujęć służących zwykłemu korzystaniu z wód. Teren ochrony pośredniej, obejmujący obszar zasilania ujęcia, wyznacza się na podstawie ustaleń z dokumentacji hydrogeologicznej.

Stefę ochronną obejmującą teren ochrony bezpośredniej i teren ochrony pośredniej ustanawia się na podstawie analizy ryzyka.

Ustawa z dnia 20 lipca 2017 r. - Prawo wodne wprowadziła obowiązek wykonywania analizy ryzyka, obejmującej identyfikację oraz ocenę zagrożeń dla jakości wód podziemnych ujmowanych w celu zaopatrzenia ludności w wodę do spożycia. W przypadku wystąpienia wysokiego ryzyka rekomendowane jest ustanowienie strefy ochronnej ujęcia obejmującej teren ochrony pośredniej. Wprowadzanie stref ochronnych przyczynia się do eliminowania i ograniczania zagrożeń przez właściwe użytkowanie terenu oraz korzystanie z wód w obszarach zasobowych ujęć.

\section{Monitoring wód podziemnych i ocena stanu JCWPd}

Zgodnie z art. 52 ustawy Prawo wodne ochrona wód jest realizowana w szczególności z uwzględnieniem wyników oceny stanu. Zgodnie z art. 349, ust. 8 ustawy Prawo wodne badania i ocenę stanu wód podziemnych w zakresie elementów fizykochemicznych i ilościowych wykonuje państwowa służba hydrogeologiczna. Zadania te stanowią element Państwowego Monitoringu Środowiska i służą pozyskaniu informacji o stanie wód podziemnych na potrzeby planowania w gospodarowaniu wodami oraz oceny osiągania celów środowiskowych. Wyniki oceny stanu JCWPd w powiązaniu z wynikiem analizy presji i oddziaływań stanowią podstawę do podejmowania działań naprawczych ukierunkowanych na redukcję presji, ograniczenie zanieczyszczenia oraz w efekcie osiągnięcie celów środowiskowych, co bezpośrednio przekłada się na ochronę wód.

Aktualnie obowiązująca ocena stanu jednolitych części wód podziemnych wykonana została w 2020 r. i opierała się na przeprowadzeniu dziewięciu testów klasyfikacyjnych oraz dwóch analiz wspierających, ukierunkowanych na potrzeby różnych odbiorców wód podziemnych tzw. receptorów (ekosystemy lądowe zależne od wód podziemnych, wody powierzchniowe, wody przeznaczone do spożycia). Końcowa ocena stanu JCWPd jest rezultatem agregacji wyników wszystkich testów klasyfikacyjnych. Warunkiem koniecznym do stwierdzenia dobrego stanu w badanej JCWPd jest pozytywny wynik oceny stanu wszystkich testów.

W wyniku przeprowadzonej w 2020 r. procedury oceny stanu JCWPd, na podstawie wyników monitoringu diagnostycznego z 2019 r., stwierdzono, że (ryc. 6 i 7):

- liczba JCWPd o stanie dobrym wynosi 151, a o stanie słabym 21 ;

- liczba JCWPd o dobrym stanie chemicznym wynosi 163, a o stanie słabym 9;

- liczba JCWPd o dobrym stanie ilościowym wynosi 157, a o stanie słabym 15;

- w porównaniu z oceną stanu wg danych z 2016 r., 160 JCWPd utrzymało swój stan. Dotyczyło to 144. JCWPd o stanie dobrym i 16. JCWPd o stanie słabym;

- utrzymujący się stan słaby stwierdzono w 15. JCWPd, o numerach: 1, 43, 62, 70, 83, $105,111,129,130,135,143,145,146,157$ i 164; 
- zmianę ze stanu dobrego na stan słaby stwierdzono w 6. JCWPd, o numerach: 9, 64, 79, $124,127,147$;

- zmianę ze stanu słabego na stan dobry stwierdzono w 7. JCWPd, o numerach: 15, 18, $39,60,110,132,156$;

- powierzchnia JCWPd, w których stwierdzono dobry stan, wynosi $285605,25 \mathrm{~km}^{2}$, co stanowi 91,61\% powierzchni całego kraju;

- powierzchnia JCWPd, w których stwierdzono słaby stan, wynosi $26168,43 \mathrm{~km}^{2}$, co stanowi jedynie 8,39\% powierzchni kraju (Palak-Mazur i in. 2020b).

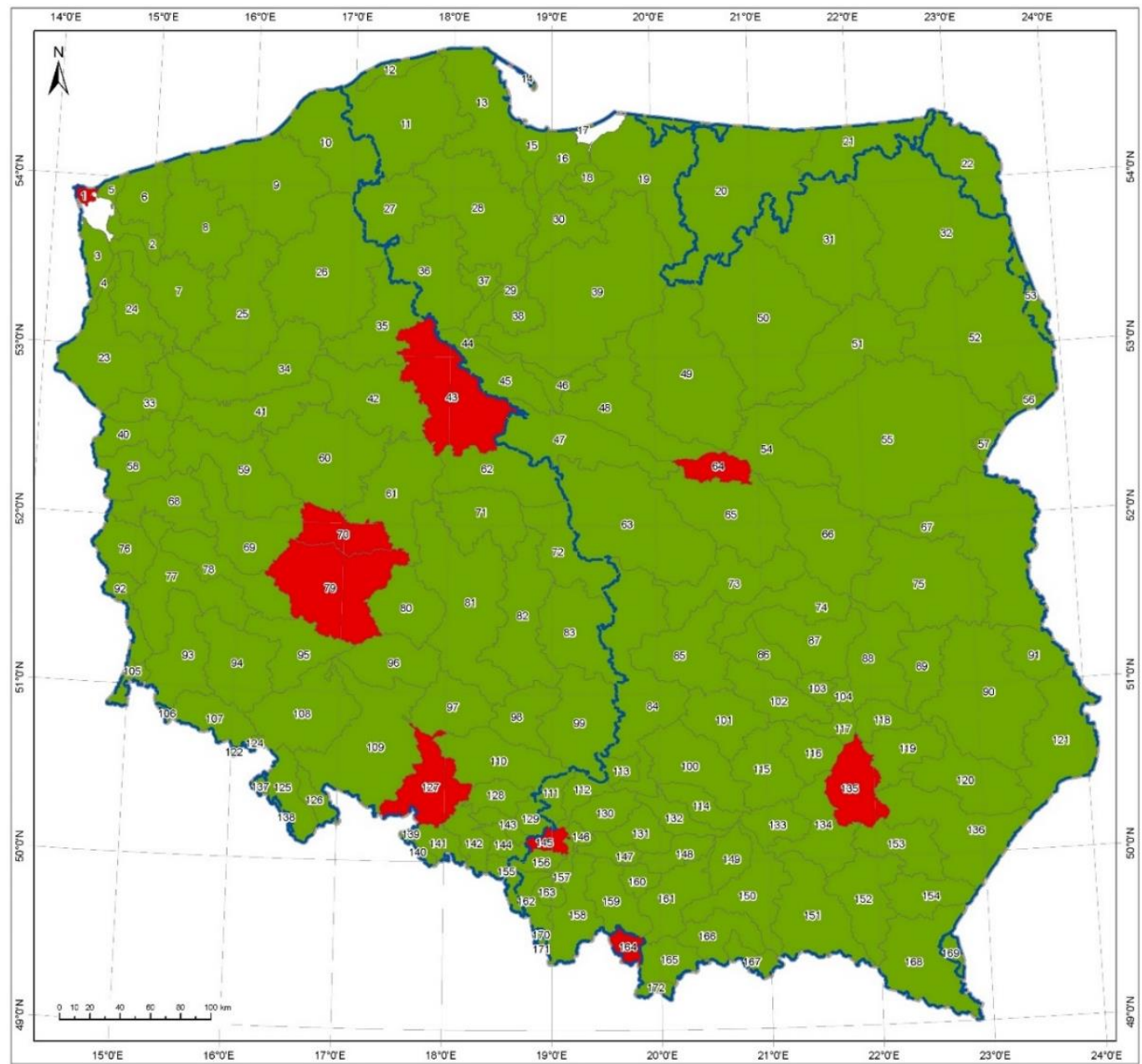

STAN CHEMICZNY JCWPd

stan dobry - dostateczna wiarygodność oceny

stan słaby - dostateczna wiarygodność oceny
241 granica i numer JCWPd (172)* * - podział na 172 JCWPd (dane PSH)

granica dorzecza

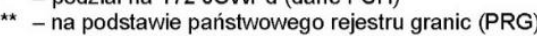

Ryc. 6. Wynik oceny stanu chemicznego JCWPd - ocena wykonana w 2020 r. wg wyników monitoringu diagnostycznego z 2019 r.

Źródło: Państwowa Służba Hydrogeologiczna 
Funkcjonowanie systemu ochrony wód podziemnych w Polsce w świetle przepisów ustawy Prawo wodne

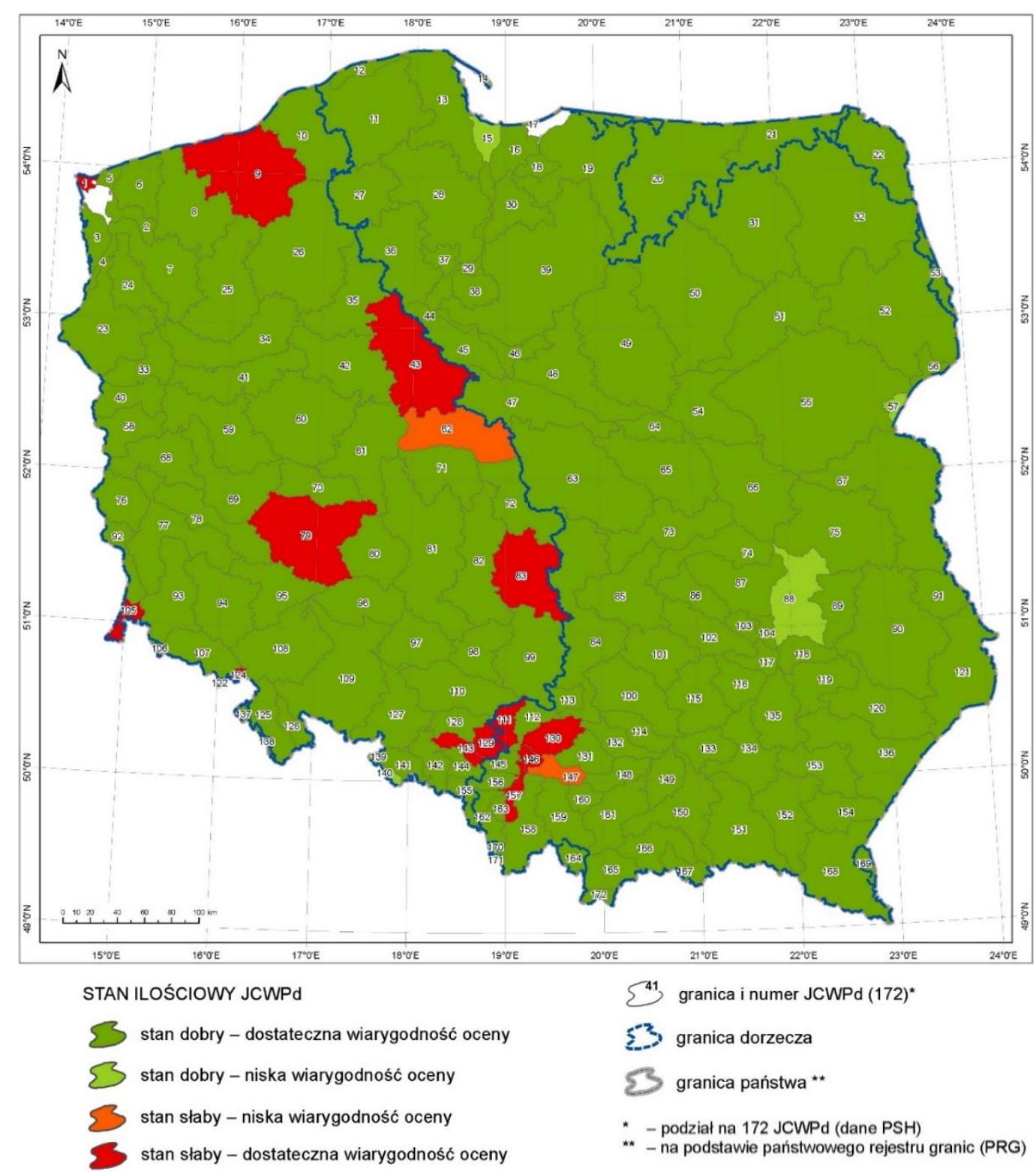

Ryc. 7. Wynik oceny stanu ilościowego JCWPd - ocena wykonana w 2020 r. wg danych z 2019 r.

Źródło: Państwowa Służba Hydrogeologiczna

Warto także zaznaczyć, że zgodnie z przepisami Rozporządzenia Ministra Gospodarki Morskiej i Żeglugi Śródlądowej z dnia 9 października 2019 r. w sprawie form i sposobu prowadzenia monitoringu jednolitych części wód powierzchniowych i jednolitych części wód podziemnych (Dz.U. z 2019 r., poz. 2147), monitoring jednolitych części wód podziemnych prowadzi się w sposób umożliwiający wykrycie znaczących i utrzymujących się trendów wzrostu stężeń zanieczyszczeń spowodowanych oddziaływaniami antropogenicznymi (§ 11, pkt. 2). 
W ramach oceny stanu przeprowadzana jest analiza tendencji wartości stężeń wskaźników fizyczno-chemicznych oraz identyfikacja znaczących i utrzymujących się trendów wzrostowych stężeń zanieczyszczeń (Palak-Mazur i in. 2020a). Znaczący i utrzymujący się trend wzrostowy oznacza każdy statystycznie i pod względem środowiskowym istotny wzrost stężenia zanieczyszczeń w wodach podziemnych, w związku z którym istnieje konieczność odwrócenia tego trendu. Zgodnie z Dyrektywą Wód Podziemnych (Załącznik IV, część B, punkt 1), punktem początkowym inicjowania działan mających odwrócić znaczące i utrzymujące się trendy wzrostowe jest stan, kiedy stężenie zanieczyszczenia osiąga 75\% wartości parametrów norm jakości wód podziemnych określonych w załączniku I oraz wartości progowych ustalonych zgodnie z art. 3 DWP i określonych w Rozporządzeniu MGMiŻŚ z dnia 9 października 2019 r. w sprawie kryteriów i sposobu oceny stanu wód podziemnych (Dz.U. z 2019 r., poz. 2147).

W ramach analizy tendencji zmian stężeń zanieczyszczeń w punktach wykonywana jest także prognoza wartości stężeń poszczególnych wskaźników, poprzez przedłużenie linii trendu do końca danego cyklu planistycznego. W przepisach prawnych nie ma odniesienia do prognozowania analiz szeregów czasowych, niemniej jednak przewidywanie znaczących i utrzymujących się trendów wzrostowych w kolejnym cyklu planistycznym jest ważnym elementem w śledzeniu zmian stężeń zanieczyszczeń i daje możliwość oceny ryzyka nieosiągnięcia bądź nieutrzymania dobrego stanu (Palak-Mazur i in. 2020a). Analiza tendencji wartości stężeń wskaźników fizyczno-chemicznych na reprezentatywnych danych z monitorowania, a także identyfikacja znaczących i utrzymujących się trendów wzrostowych stężeń zanieczyszczeń daje możliwość pozyskania spójnej i całościowej oceny stanu chemicznego wód podziemnych. Pozwala także, na odpowiednim poziomie pewności i precyzji, odróżnić zmiany naturalne od zmian antropologicznych. Dzięki temu odpowiednio wcześnie można zastosować środki mające na celu zapobieżenie lub co najmniej jak największe złagodzenie istotnych dla środowiska niekorzystnych zmian w jakości wód podziemnych.

\section{Podsumowanie}

Podsumowanie niniejszego opracowania skłania do zadania podstawowego pytania: czy funkcjonujące w Polsce rozwiązania prawne służące ochronie zasobów wodnych są wystarczające? Czy obowiązujące przepisy, zasady i procedury spełniają swoją rolę i służą efektywnej ochronie wód podziemnych, zarówno w zakresie stanu ilościowego jaki i chemicznego (jakości wód)?

Odpowiedź nie jest ani prosta ani jednoznaczna, gdyż z jednej strony zgodnie z wynikami oceny stanu JCWPd, słaby stan wód stwierdzono na niewiele ponad 8\% powierzchni kraju. Porównując je $\mathrm{z}$ wynikami z poprzednich lat w skali kraju nie stwierdza się pogorszenia stanu wód podziemnych, a wręcz widoczna jest niewielka poprawa, co także przemawia za pozytywną oceną systemu ochrony wód w Polsce. Należy jednak pamiętać o ograniczeniach oceny stanu JCWPd, na której wynik i wiarygodność przekłada się wiele elementów i ograniczeń, od reprezentatywności sieci monitoringu wód podziemnych po dostępność i wiarygodność danych wejściowych. Nie do pominięcia jest także efekt skali wykonywanej oceny - wydzielone w Polsce JCWPd są dość dużymi jednostkami i dlatego np. zanieczyszczenia stwierdzone w skali lokalnej giną $\mathrm{w}$ procedurze oceny w skali regionalnej. 
W odniesieniu do stanu ilościowego z kolei dużym ograniczeniem jest brak informacji na temat wielkości poboru nierejestrowanego, który w ocenie jest uwzględniany jedynie w sposób szacunkowy, a tym samym pomijane jest jego regionalne zróżnicowanie.

Dalszy rozwój sieci monitoringu wód podziemnych, integracja danych o presjach na poziomie ogólnokrajowym oraz innych danych środowiskowych, przyczynią się do sukcesywnego zwiększania stopnia rozpoznania stanu wód w Polsce i umożliwią podejmowanie działań naprawczych dobrze ukierunkowanych na redukcję presji lub łagodzenie jej skutków.

$Z$ drugiej strony na efektywność systemu ochrony zasobów wodnych ma także wpływ przejrzystość obowiązujących przepisów i procedur, a także sposób ich przestrzegania. Skomplikowane i długotrwałe procedury sprzyjają działaniom ukierunkowanym na ich pomijanie. Podobny wpływ mają nieefektywne systemy kontroli w gospodarowaniu wodami oraz brak lub niewystarczające sankcje za naruszanie przepisów. Jest to spotykanie zarówno w odniesieniu do stanu chemicznego (np. niekontrolowane wylewanie ścieków lub gnojowicy), jak też do stanu ilościowego (np. wykonywanie studni bez projektów robót geologicznych i pobór wód bez pozwolenia wodnoprawnego).

Wciąż bardzo wiele jest do zrobienia w zakresie działań edukacyjnych i podnoszenia świadomości społecznej na temat warunków występowania wód podziemnych, ich użytkowania i roli jakiej pełnią zarówno w środowisku, jak i w zaspokajaniu potrzeb wodnych ludności i gospodarki. Ramowa Dyrektywa Wodna kładzie duży nacisk na udział społeczeństwa w planowaniu i realizacji działań mających na celu utrzymanie bądź osiągnięcie celów środowiskowych dla wód. Jednak zaangażowanie społeczne w tym zakresie w Polsce nadal wydaje się być niewystarczające.

\section{Bibliografia}

Felter A., Forst Sz., Gałkowski P., Herbich P., Mikołajków J., Mordzonek G., Mikołajczyk A., Przytuła E., Węglarz D., 2012, Zadania Systemu Przetwarzania Danych Państwowej Shużby Hydrogeologicznej - rozpoznawanie, bilansowanie i ochrona wód podziemnych, PZTiS, 19(1): 37-59.

Frankowski Z., Gałkowski P., Mitręga J., 2009, Struktura poboru wód podziemnych w Polsce, Informator Państwowej Służby Hydrogeologicznej, PIG-PIB.

Herbich P., Mikołajków J., Skrzypczyk L., 2011, Wybrane problemy ustanawiania obszarów ochronnych głównych zbiorników wód podziemnych, Biuletyn Państwowego Instytutu Geologicznego, 445: 179-192.

Herbich P., Kapuściński J., Nowicki K., Rodzoch A., 2013, Metodyka określania zasobów dyspozycyjnych wód podziemnych $w$ obszarach bilansowych z uwzględnieniem potrzeb jednolitych bilansów wodnogospodarczych, Poradnik metodyczny, Ministerstwo Środowiska.

Chmielewska J., Jezierski H.J., 2004, Europejskie instrumenty prawne ochrony wód podziemnych - co nas czeka po wejściu do Unii Europejskiej?, [w:] Materiały XV Sympozjum naukowo-technicznego: Gospodarowanie wodami podziemnymi w Unii Europejskiej, PZTiS, 15(1): 1-11. 
Matusiak M., Przybyłek J., 2017, Wykorzystanie niestacjonarnego modelu przepływu do oceny rzeczywistej wielkości eksploatacji wód podziemnych z piętra jurajsko-kredowego na obszarze intensywnych nawodnień rolniczych $w$ rejonie Kalisza, Przegląd Geologiczny, 65(11/2): 1218-1224.

Palak-Mazur D., Stojek M., Kowalczyk A., Mikołajczyk A., Felter A., Piskorek K., Połujan-Kowalczyk M., Przytuła E., Solovey T., Janica R., Galczak M., Gidziński T., Cabalska J., Rojek A., Kuczyńska A., Razowska-Jaworek L., Woźnicka M., 2020a, Aktualizacja metodyki oceny stanu JCWPd wraz z opracowaniem metodyki analizy odwracania trendów zanieczyszczeń (Wykonano w ramach realizacji Etapu III umowy nr 25/2018/F z dnia 12.07.2018 r., pt. Monitoring stanu chemicznego oraz ocena stanu jednolitych części wód podziemnych w dorzeczach w latach 2018-2021, na zlecenie Głównego Inspektoratu Ochrony Środowiska), PIG-PIB.

Palak-Mazur D., Stojek M., Kowalczyk A., Mikołajczyk A., Felter A., Piskorek K., Połujan-Kowalczyk M., Przytuła E., Solovey T., Janica R., Galczak M., Gidziński T., Cabalska J., Rojek A., Kuczyńska A., Razowska-Jaworek L., Woźnicka M., 2020b, Opracowanie oceny stanu chemicznego i ilościowego jednolitych części wód podziemnych $w$ dorzeczach (Wykonano w ramach realizacji Etapu V umowy nr 25/2018/F z dnia 12.07.2018 r., pt. Monitoring stanu chemicznego oraz ocena stanu jednolitych części wód podziemnych w dorzeczach w latach 2018-2021, na zlecenie Głównego Inspektoratu Ochrony Środowiska), PIG-PIB.

Przytuła E., 2015, Programy prac i dokumentacje hydrogeologiczne ustalajace zasoby dyspozycyjne wód podziemnych na potrzeby przeprowadzania bilansów wodnogospodarczych oraz opracowania warunków korzystania $z$ wód regionu wodnego $i$ zlewni - założenia metodyczne, stan realizacji przedsięwzięcia, Przegląd Geologiczny, 63 (10/2): 1027-1032.

Rozporządzenie Ministra Gospodarki Morskiej i Żeglugi Śródlądowej z dnia 11 października 2019 r. $w$ sprawie kryteriów i sposobu oceny stanu jednolitych części wód podziemnych (Dz.U. z 2019 r., poz. 2148).

Rozporządzenie Ministra Gospodarki Morskiej i Żeglugi Śródlądowej z dnia 9 października 2019 r. $w$ sprawie form i sposobu prowadzenia monitoringu jednolitych części wód powierzchniowych i jednolitych części wód podziemnych (Dz.U. z 2019 r., poz. 2147).

Sadurski A., 2004, Zadania ochrony wód podziemnych wynikajace z Ramowej Dyrektywy Wodnej UE, Przegląd Geologiczny, 52(10): 1004-1005.

Sadurski A., 2015, Problem zasobów wód podziemnych, Przegląd Geologiczny, 63(10/2): 1047-1052.

Sadurski A., Przytuła E., 2016, Zasoby dyspozycyjne wód podziemnych dorzeczy w Polsce $w$ świetle zrównoważonego gospodarowania wodami, Biuletyn Państwowego Instytutu Geologicznego, 466: 261-270.

Ustawa z dnia 20 lipca 2017 r. Prawo wodne (Dz. U. z 2021 r., poz. 624, 784). 
Funkcjonowanie systemu ochrony wód podziemnych w Polsce w świetle przepisów ustawy Prawo wodne

Witczak S., 2006, Ochrona jakości wód podziemnych w świetle dyrektyw UE, [w:] Materiały XVI Sympozjum naukowo-technicznego: Problemy związane z wprowadzaniem Ramowej Dyrektywy Wodnej, PZTiS, 16(1): 61-71.

Witczak S., Kania J., Żurek A., 2012, Kierunki zmian w dyrektywach Unii Europejskiej (RDW i DWP) w świetle realizacji europejskiego projektu FP7 GENESIS, [w:] Materiały XIX Sympozjum naukowo-technicznego: Gospodarowanie wodami podziemnymi w aktualnych uwarunkowaniach, PZiTS, 19(1): 3-12.

Woźnicka M., Kuczyńska A., 2019, Rewizja dyrektyw unijnych dotyczacych zarzadzania zasobami wodnymi - plany Komisji Europejskiej w zakresie nowelizacji polityki wodnej, Biuletyn Państwowego Instytutu Geologicznego, 475. 